\title{
Assessing the toxicity of ammonium pulses to the survival and growth of Zostera noltii
}

\author{
Fernando G. Brun*, Ignacio Hernández, Juan J. Vergara, Gloria Peralta, \\ J. Lucas Pérez-Lloréns
}

Departamento de Ecología, Universidad de Cádiz, Facultad de Ciencias del Mar, 11510 Puerto Real, Cádiz, Spain

\begin{abstract}
The present study assessed the effect of seawater ammonium enrichment on survival and growth of the seagrass Zostera noltii Hornem. Ammonium enrichment had an inhibitory effect on shoot, rhizome and root elongation rates, as well as on primary production. The inhibitory effect was partially alleviated by phosphate addition. The frequency of ammonium pulses also affected growth negatively, with a maximum effect at both low and high pulse frequencies. Similar results were obtained when the experiment was run in the field during a winter trial. However, when the field experiment was repeated in spring at higher mean temperature and irradiance levels, opposite results were obtained, with ammonium enrichment causing a substantial increase in growth rates and productivity. These responses were related to the internal balance of non-structural carbohydrates (especially sucrose) with respect to $\mathrm{C}$ and $\mathrm{N}$ cell metabolism. Thus, there was a mobilisation of sucrose in both above- and belowground tissues to meet $\mathrm{C}$ increased demands arising from ammonium assimilation in winter, with sucrose concentrations reaching critical levels in relation to the total internal $\mathrm{C}$ pool. In contrast, sucrose accumulated in the tissues when ammonium pulses were applied in spring, indicating an enhanced $\mathrm{C}$ turnover that was able to meet the increased demands arising from ammonium assimilation into organic $\mathrm{N}$ compounds.
\end{abstract}

KEY WORDS: Ammonium · Eutrophication · Nitrogen · Primary production · Seagrass $\cdot$ Sucrose Zostera noltii

\section{INTRODUCTION}

In coastal and estuarine waters worldwide, seagrasses are declining as a result of natural and humaninduced disturbances (Short \& Wyllie-Echevarria 1996), including eutrophication (Short et al. 1995). The increase in nutrient content in coastal waters has led to the proliferation of masses of green algae (Hernández et al. 1997, Valiela et al. 1997), heavy epiphyte loads (Neckles et al. 1993), and a decrease in the underlying seagrasses (Valiela et al. 1997, Mann 2000). Increased nitrogen loading has often been pointed out as one of the main causes that lead to the decline of seagrass populations (van Katwijk et al. 1997, Touchette \& Burkholder 2000a). An increase in nitro-

*E-mail: fernando.brun@uca.es gen loading can reduce seagrass productivity by stimulating competition for available light due to the outbreak of fast-growing algae (e.g. phytoplankton, epiphytic algae or various species of free-floating algae) (Williams \& Ruckelshaus 1993), which may result in substantial seagrass losses (Short et al. 1995, Valiela et al. 1997). In addition, mesocosm experiments have shown direct nitrate (Burkholder et al. 1992) and ammonium toxicity (van Katwijk et al. 1997) in Zostera marina L. This species takes up inorganic nitrogen through the leaves and roots (Short \& McRoy 1984, Risgaard-Petersen et al. 1998) and ammonium usually seems to be a more important source of nitrogen than nitrate (Zimmerman et al. 1987).

The harmful effect of ammonium on seagrasses has only been tested in Zostera marina (van Katwijk et al. 1997), in which the ammonium toxicity seems to be strongest when irradiance is low but temperature is 
high. Physiologically, the main toxic effect of ammonium is thought to lie in the uncoupling of ATP synthesis from photosynthetic electron transport (Marschner 1995).

Along the southern coast of Spain, marked declines in Zostera noltii populations have been reported (Carreira et al. 1995, Hernández et al. 1997). These declines have mainly been attributed to increasing eutrophication. In some coastal zones of this area, such as the Palmones river estuary, ammonium pulses with concentrations up to $200 \mu \mathrm{M}$ have been measured at low tide, and concentrations are overall high enough to suggest no nitrogen limitation (Hernández et al. 1997).

The aim of this work was to assess the toxicity of ammonium in Zostera noltii. We tested the effect of periodic ammonium and/or phosphate addition, as well as the effect of ammonium pulses of different frequency, under both laboratory and field conditions. The effect of ammonium enrichment was examined by monitoring the dynamic response of the plant, i.e. growth rates, production of both above- and belowground tissues, plastochron interval and leaf-loss time. Also, the elemental C:N:P composition, and non-structural carbohydrates (sucrose and starch) were examined to analyse the response to ammonium enrichment.

\section{MATERIALS AND METHODS}

Sampling site and plant collection. Plants of Zostera noltii were collected in winter (1998/99) and spring (1999) from intertidal muddy beds at Los Toruños, a salt-marsh ecosystem of 773 ha situated in the Cadiz Bay Natural Park (Fig. 1). The area is surrounded by a spit, $12 \mathrm{~km}$ in length and with a maximum depth of $4 \mathrm{~m}$. The system can be considered as meso-eutrophic, with nutrient concentrations in the sampling site varying broadly throughout the year and as a function of tidal state. Maximum nutrient concentrations usually occur in winter, with values up to $1.4 \mu \mathrm{M} \mathrm{NO}_{2}{ }^{-}, 12 \mu \mathrm{M}$ $\mathrm{NO}_{3}{ }^{-}, 25 \mu \mathrm{M} \mathrm{NH}{ }_{4}{ }^{+}$and $1.5 \mu \mathrm{M} \mathrm{PO}{ }_{4}{ }^{3-}$ (GonzálezGordillo 1999, Tovar et al. 2000). (For further information on physical and chemical variables at the sampling site see Tovar et al. 2000).

Apical shoots (those exhibiting the apical dominance of a large, branched plant) of Zostera noltii were selected from the field. Immediately after collection, the shoots were transported to the laboratory (10 $\mathrm{min}$ from the sampling site) in an ice-chest. Upon arrival, and before experimental set up, they were rinsed in seawater and visible epiphytes were removed by gentle scraping. Shoot length was measured and marked at $1 \mathrm{~cm}$ above the bundle sheath to estimate growth rates by the punching method (Zieman 1974 as modified by Peralta et al. 2000a). The plants were then allocated to the respective experimental set up (see next subsection), where they remained overnight at $15^{\circ} \mathrm{C}$. The experiments started the following day.

Laboratory experiments. For standardisation, 4 winter plants consisting of 1 apical shoot (4 to 5 leaves) with 2 rhizome internodes, and corresponding roots were transplanted in an agar-solidified substratum in a glass crystallyzer (Peralta et al. 2000b). The substratum consisted of an agar-solidified root-rhizome layer ( $2 \%$ agar w/v). Unenriched artificial seawater (marine culture medium without nitrate and phosphate; Woelkerling et al. 1983) was used as a solvent. The crystallyzer with the plants was placed in a methacrylate jar $(900 \mathrm{ml})$ filled with filtered (Whatman GF/C) natural seawater. This water had previously contained healthy Ulva spp. thalli for $3 \mathrm{~d}$ to decrease the nutrient concentration. The the jars were then placed in a 401 aquarium filled with distilled water and connected to a temperature-

Fig. 1. Sampling and field experimental site in Los Toruños, a salt marsh in the Cádiz Bay Natural Park 
controlled $\left(18.5^{\circ} \mathrm{C}\right)$ thermostatic bath by a closed circuit. Light was supplied on a 12:12 light:dark cycle; cool fluorescent lights (Phillips TL20W/54RS) provided about $210 \mu \mathrm{mol}$ photons $\mathrm{m}^{-2} \mathrm{~s}^{-1}$ at the base of the plants, as measured by a LI-193SA spherical quantum sensor.

The first experiment was designed to study the effect of an increased nutrient loading on the growth of Zostera noltii. The experiment consisted of 4 different treatments: $+\mathrm{P}$ (seawater enriched with $1 \mu \mathrm{M} \mathrm{PO}{ }_{4}{ }^{3-}$ ), $+\mathrm{N}$ (seawater enriched with $16 \mu \mathrm{M} \mathrm{NH}_{4}{ }^{+}$), $+\mathrm{N}+\mathrm{P}$ (both nutrients added), and a control without nutrient enrichment. Jars $(n=2)$ were randomly placed in the aquarium. Each jar was replenished every $2 \mathrm{~d}$ from its own stock container. The jars were gently air bubbled to ensure complete mixing. After $16 \mathrm{~d}$ culture, the plants were harvested for plant analyses (see 'Plant analysis' below).

Once the ammonium toxic effect had been established, another experiment was performed to assess the effect of different pulses (frequencies) of ammonium addition on the survival and growth rates of Zostera noltii. The experimental set up was similar to that described above, except for nutrient enrichment. In this case a final dose of ammonium $(200 \mu \mathrm{M})$ was added to all the jars. Four treatments were run in duplicate: 1 pulse (seawater enriched with $200 \mu \mathrm{M}$ $\mathrm{NH}_{4}{ }^{+}$at the beginning of the experiment), 2 pulses of $100 \mathrm{\mu M} \mathrm{NH}_{4}{ }^{+}$(Days 0 and 8), 4 pulses of $50 \mu \mathrm{M} \mathrm{NH}_{4}{ }^{+}$ (Days $0,4,8$ and 12), and 8 pulses of $25 \mu \mathrm{M}$ $\mathrm{NH}_{4}{ }^{+},(1$ every $2 \mathrm{~d}$ ). In each case, $0.5 \mu \mathrm{M}$ phosphate was added to the jars every $2 \mathrm{~d}$ to prevent phosphorus limitation. Four apical shoots were cultured per jar. After 16 d culture, the plants were removed and measured (see 'Plant analysis' below).

Field experiments. On 2 occasions, winter (December 1998) and spring (April 1999), additional experiments were carried out to study the effect of ammonium pulses on the survival and growth rates of Zostera noltii in the field, to complement the results obtained in the laboratory. We manipulated the ammonium supply to a selected intertidal plot in Los Toruños by fertilising an experimental $Z$. noltii bed, as in previous field enrichment designs (see Foreman et al. 1995, Pedersen \& Borum 1996). The selected experimental bed $\left(150 \mathrm{~m}^{2}\right)$ was in a shallow intertidal lagoon $(30 \mathrm{~cm}$ depth at low tide), where the water flow was low at high tide. The tide is semidiurnal, with a mean range of $2.5 \mathrm{~m}$ (Gómez-Parra 1978), although unpredictable fluctuations in water level can be caused by the wind. The experimental design is shown in Fig. 2. Fourteen uncapped Eppendorf $^{\odot}$ vials $(1.5 \mathrm{ml})$ were filled with a $5 \mathrm{M} \mathrm{NH}_{4}{ }^{+}$agar-solidified solution, and a small hole was made at the bottom to allow ammonium diffusion. The vial was then hermetically seated in a $5 \mathrm{ml}$ plastic bottle filled with the enriched agar-solidified solution. Finally, the plastic bottle was capped. A hole was also punched into this cap to allow gentle diffusion of the ammonium into the experimental Z. noltii plot, with the Eppendorf ${ }^{\odot}$ vial operating inside as an additional ammonium reservoir. The suitability of this design (i.e. ammonium diffusion into seawater) had previously been tested in the laboratory. In the field, the ammonium containers (Eppendorf ${ }^{\odot}$ vial plus plastic bottle) were placed in a plastic net surrounding the crystallyzer and the plants. Five apical shoots were placed in the agar-solidified substratum as above. The crystallyzer with the plants was placed on the sediment, and the ammonium containers were gently pushed into the sediment. Finally, a methacrylate core (16 $\mathrm{cm}$ in diameter, $7 \mathrm{~cm}$ high) was placed around the whole unit to promote high ammonium conditions around the plants and encourage vertical diffusion of the nutrient. As in the laboratory experiment, the same ammonium dose (14 containers of $5 \mathrm{M} \mathrm{NH}_{4}^{+}$) was applied at different frequencies: 1 pulse (14 containers added at the beginning of the experiment); 2 pulses ( 7 containers at Days 0 and 8 ); 4 pulses (4 containers at Days 0 and 8, and 3 containers at Days 4 and 12); 7 pulses (2 containers, at Days $0,3,5,8,10,12$ and 14);

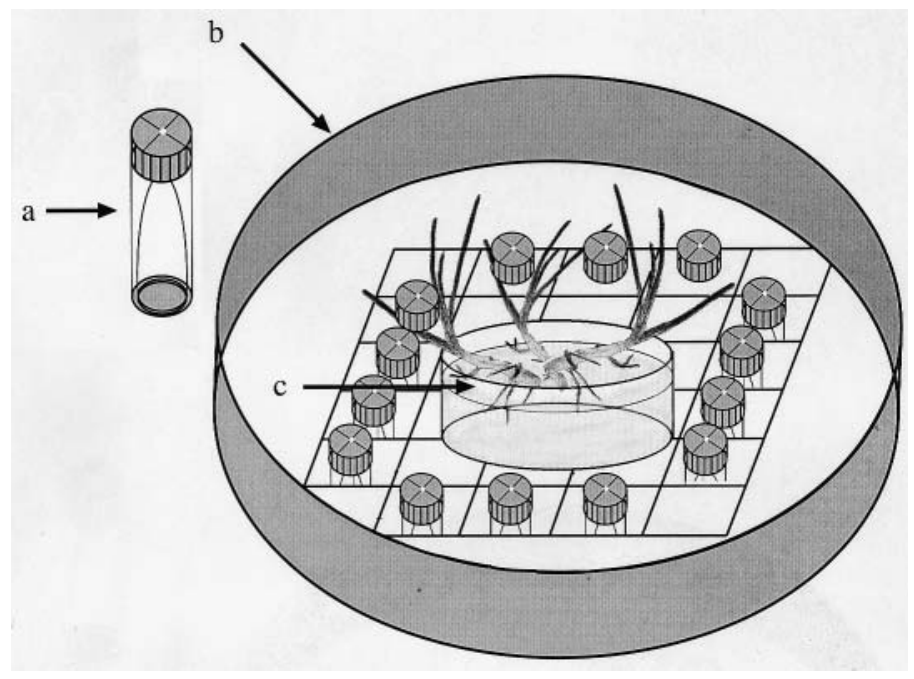

Fig. 2. Experimental design to simulate different pulses of ammonium amendment in the field. The same ammonium dose (14 containers of $5 \mathrm{M} \mathrm{NH}_{4}{ }^{+}$) was added at different frequencies during the experiment to mimic pulses of the nutrient enrichment. a: capped plastic bottle, filled with ammonium agar-solidified solution and containing an

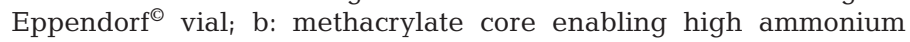
conditions and encouraging vertical diffusion around the plants $(\mathrm{n}=$ 4 to 5); c: glass crystallyzer with apical shoots transplanted in agarsolidified substratum 
and a control (no ammonium enrichment). A total dose of $0.35 \mathrm{~mol}$ ammonium was applied during the experiment. The different treatments were placed apart and uniformly to assure no interference between them. Each treatment was run in duplicate. After $16 \mathrm{~d}$ under these conditions, the plants were removed and measured (see next subsection).

Plant analysis. After each experiment, the plants were harvested and those parts that had grown since marking were separated from those present at the time of marking to estimate shoot- $\left(\mathrm{cm} \mathrm{d}^{-1}\right.$ plant $\left.^{-1}\right)$, rhizome$\left(\mathrm{cm} \mathrm{d}^{-1}\right.$ plant $\left.^{-1}\right)$ and root-elongation rates $\left(\mathrm{cm} \mathrm{d}^{-1}\right.$ plant $^{-1}$ ). The plastochron interval (time between the formation of 2 consecutive leaves from the same meristem) and the leaf-loss time (time elapsed before the oldest leaf was lost) were calculated by the punched holes method, as modified by Peralta et al. (2000a). Shoot losses (i.e. those found floating free in the jars during the experiments) were expressed as $\mathrm{cm} \mathrm{d}^{-1}$ plant $^{-1}$. Any new tissue produced (leaves, rhizomes or roots) was dried at $60^{\circ} \mathrm{C}$ for $24 \mathrm{~h}$ to estimate dry weight. Primary production was expressed as mg dry wt plant ${ }^{-1} \mathrm{~d}^{-1}$. The tissue nutrient concentration was measured in pooled samples of ground dry tissue (aboveand belowground parts). The initial and final concentrations of internal $\mathrm{P}$ were quantified by the persulphate digestion method (APHA 1992). Other subsamples of tissue were used to determine $\mathrm{C}$ and $\mathrm{N}$ concentrations, using a CHN elemental analyser (Perkin-Elmer 240 C). Non-structural carbohydrates (sucrose and starch) were measured following Alcoverro et al. (1999).

Biostatistical analyses. Differences between treatments were tested by a hierarchical (nested) analysis of variance (ANOVA). The levels of variability were the jars in every treatment $(n=2)$ and the plants within each jar ( $\mathrm{n}=4$ to 5 ). The experimental units (jars) did not differ significantly during each treatment. Homogeneity of variances had been previously tested (Zar 1984), and multiple post-hoc comparisons between means were assessed by the Tukey procedure (Zar 1984). In all cases, the significance level was set at $5 \%$ probability.

\section{RESULTS}

\section{Plant response}

Ammonium, and to a much less extent phosphate, addition significantly influenced Zostera noltii Hornem growth. Plants enriched exclusively with ammonium showed significantly lower shoot-, rhizome- and rootelongation rates than the control (Fig. 3). However, phosphate addition, even together with ammonium enrichment, affected only the root-elongation rate significantly (Fig. 3C), with no effect on shoot- or rhizome-elongation rates. Leaf-loss rate was also significantly influenced by ammonium alone (Fig. 3A), while phosphorus enrichment had no significant effect.

As a result, primary production of Zostera noltii was also affected by ammonium addition (Fig. 4). Plants enriched with ammonium alone showed the lowest total production (1.6 mg dry wt plant ${ }^{-1} \mathrm{~d}^{-1}$; above- and belowground tissues). This negative effect was partially alleviated (although production was still significantly lower than control values) in the cultures receiving both $\mathrm{P}$ and N. No significant effect was observed when cultures were enriched with phosphate alone. The major effect of ammonium addition was on root production, which ceased almost completely, followed by rhizome production; leaf production was less affected. Ammonium enrichment also significantly increased the plastochron interval and decreased the leaf-loss time (Fig. 4B). Neither effect was observed in the cultures receiving phosphate, either alone or combined with ammonium.

The toxic effect of ammonium was further investigated with different frequencies (pulses) of enrichment. When all the ammonium had been added at the beginning (1 pulse) or was evenly spread throughout the experiment (8 pulses), the negative effect was most evident (Fig. 5). Shoot-elongation rate was not affected significantly by 2 or 4 pulses of ammonium (Fig. 5A). The lowest shoot-elongation rate $\left(0.5 \mathrm{~cm} \mathrm{~d}^{-1}\right.$ plant $\left.^{-1}\right)$ was recorded when high ammonium conditions were constant throughout cultivation (8 pulses of $25 \mu \mathrm{M}$ ). The toxic effect of ammonium enrichment was evident in leaf-loss rates, which were always affected significantly (Fig. 5A). These rates were similar to those observed after $16 \mu \mathrm{M} \mathrm{NH}{ }_{4}{ }^{+}$enrichment (see above experiment). Similarly, rhizome- and root-elongation rates were significantly lower than the control (Fig. 5B,C). The lowest toxic effect was observed with 2 ammonium pulses of $100 \mu \mathrm{M}$. Again, elongation rates of above- and belowground tissues under different pulses were similar to those observed previously when plants were enriched with ammonium, either alone or with phosphate.

The toxic effect was also evident in the significantly lower production (above- and belowground tissues) of Zostera noltii with ammonium pulses compared to the control. The lowest effect was recorded for 2 pulses of $100 \mu \mathrm{M}$ (Fig. 6A). Ammonium toxicity induces a larger plastochrone interval (Fig. 6B), especially after a high initial pulse of $200 \mu \mathrm{M}$ and in cultures with a more constant, chronic ammonium enrichment (8 pulses). Ammonium enrichment also decreased leaf-loss time significantly in all treatments, down to values half those of control plants (Fig. 6B). 


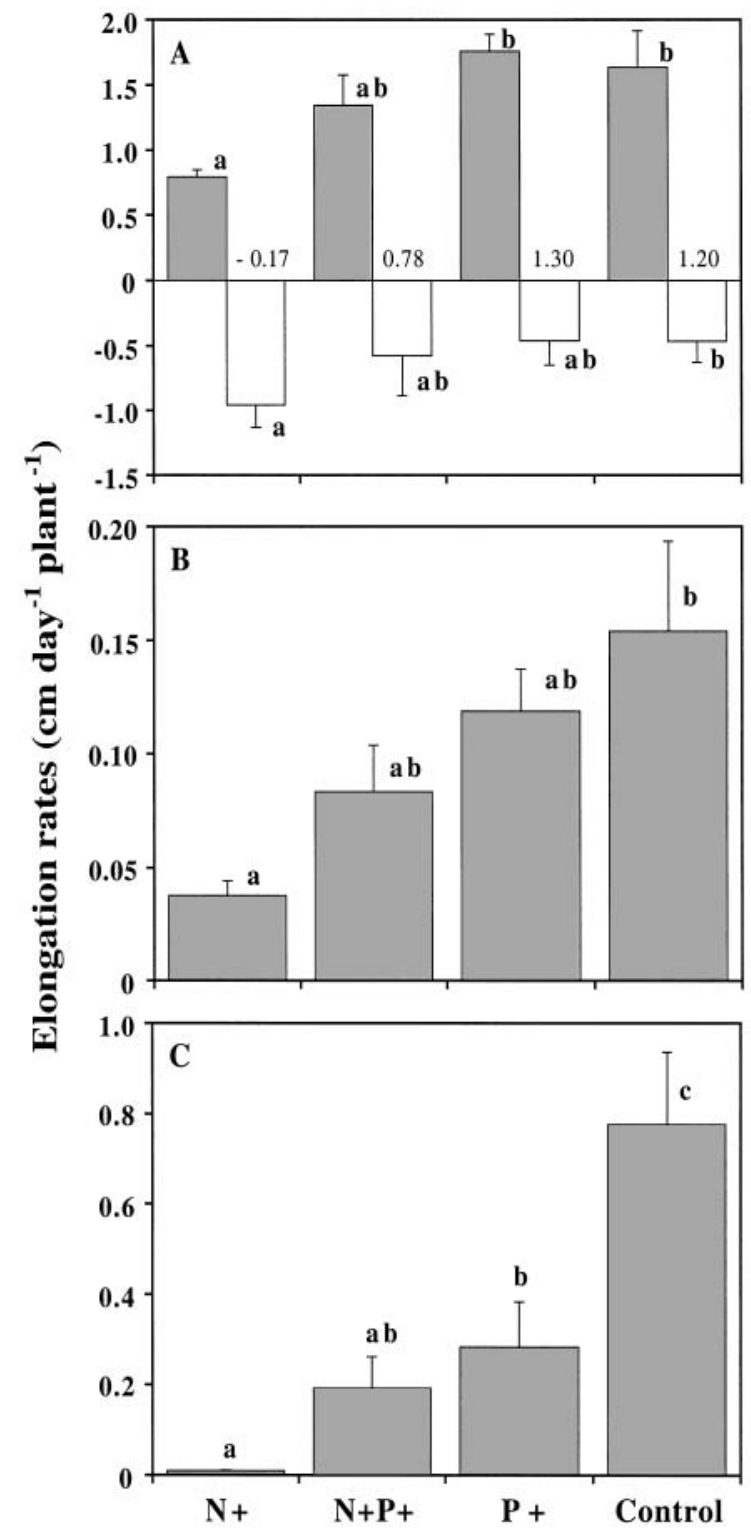

Fig. 3. Zostera noltii. Effect of ammonium and phosphate enrichment on elongation rates of (A) shoots, (B) rhizomes and $(\mathrm{C})$ roots in the laboratory. Shaded bars in (A) represent gross growth rates and open bars leaf-loss rates; numbers within the graph denote net growth rates. Different letters above bars indicate significant differences $(p<0.05)$ among means. Data are means of 6 to 8 separate plants; bars represent $\mathrm{SE}$

The results obtained in the laboratory experiments were corroborated in the field. In the winter trial, ammonium enrichment had a significantly toxic effect on shoot-elongation and leaf-loss rates (Fig. 7A), and thus on gross production. In addition, toxicity was evident with a high ammonium dose (1 pulse) or with frequent ammonium addition ( 7 pulses). Unfortunately, the cultivation period was not long enough to give accurate estimates of rhizome- or root-elongation rates. Toxicity was shown more clearly in the leaf-loss rates, which were always significantly greater than the control. As in the laboratory, ammonium enrichment in the field significantly increased the plastochron interval when 1 or 7 pulses were applied (Fig. 7B). In these 2 treatments, significantly shorter leaf-loss times were observed compared to the control.

However, this pattern was different when the field experiment was repeated in spring, with higher mean temperatures and irradiance levels. Here, ammonium enrichment caused a significant increase in shoot-, rhizome- or root-elongation rates, especially with 1 and 2 ammonium pulses (Fig. 8), suggesting a stimulating rather than a toxic effect. No significant differences were found in leaf-loss rates between the control and any ammonium-enrichment treatment. As a result total primary production increased significantly with ammonium enrichment (Fig. 9A). The ammonium pulses also significantly decreased the plastochron interval and increased the leaf-loss time compared to the control (Fig. 9B).
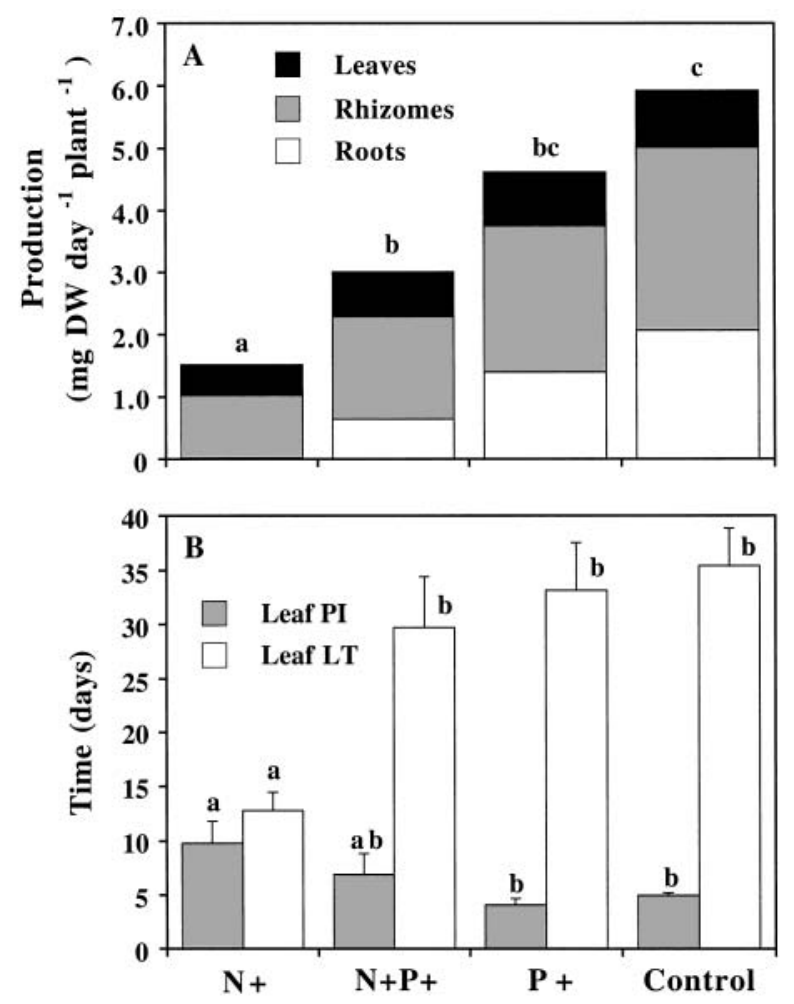

Fig. 4. Zostera noltii. Effect of ammonium and phosphate addition on (A) primary production of above- and belowground tissues in the laboratory, and (B) plastochron interval (PI) and leaf-loss time (LT). Letters above bars as in Fig. 3. Data are means of 6 to 8 separate plants; bars represent $\mathrm{SE}$ 


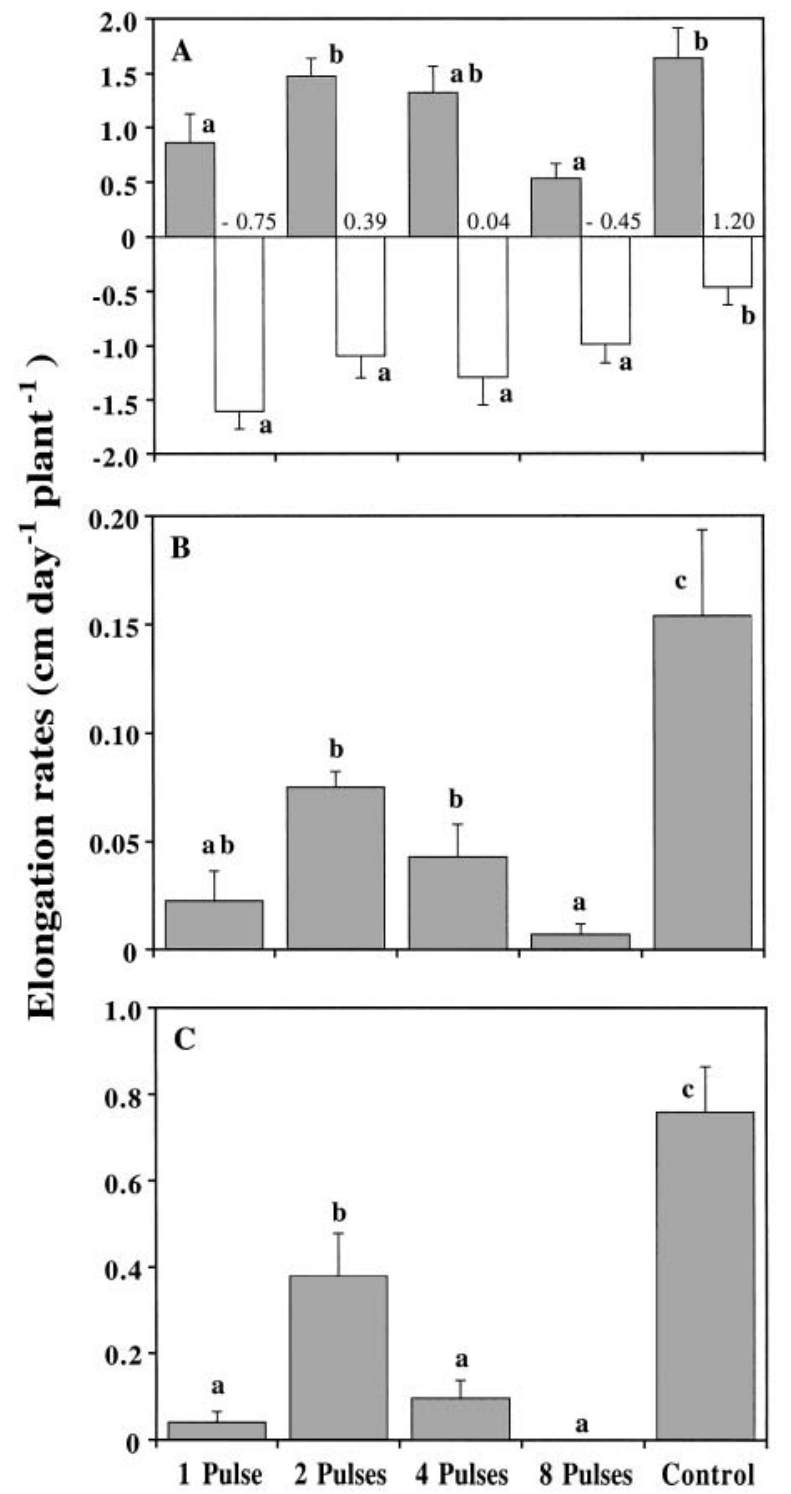

Fig. 5. Zostera noltii. Effect of the frequency of ammonium enrichment with different pulses of a similar final dose $(200 \mu \mathrm{M})$ in the laboratory on elongation rates of (A) shoots, (B) rhizomes and (C) roots. Ammonium pulses were applied as 1 pulse $(1 \times 200 \mu \mathrm{M}), 2$ pulses $(2 \times 100 \mu \mathrm{M})$, 4 pulses $(4 \times$ $50 \mu \mathrm{M})$ and 8 pulses $(8 \times 25 \mu \mathrm{M})$. Further details as in Fig. 3 legend

\section{Internal composition}

The internal C:N:P composition and the non-structural carbohydrate content were affected by nutrient enrichment. Data on internal composition in response to different nutrient combinations ( $\mathrm{N}$ and $\mathrm{P}$ ) are shown in Table 1. Internal $\mathrm{N}$ content decreased from initial values in all treatments. However, ammonium enrichment resulted in a higher $\mathrm{N}$ content compared to the other treatments. Thus, C:N ratios increased in the control and all treatments. The N:P ratios decreased in aboveground tissues, except with ammonium addition. Within the non-structural carbohydrates, starch content was approximately 1 order of magnitude lower than sucrose content, and did not show a clear response to nutrient addition. In contrast, sucrose was strongly affected by nutrient regimes. There was a strong decline in sucrose content in response to ammonium addition in aboveground and, especially, belowground tissues. In contrast, sucrose accumulated in both these tissues in the control. With $\mathrm{P}$ enrichment, sucrose accumulated in leaves, but decreased in belowground tissues, whereas it showed no great variation with the combined $\mathrm{N}$ and $\mathrm{P}$ enrichment. The proportion of sucrose-C within the $\mathrm{C}$ pool was strongly influenced by nutrient regime, reaching its lowest values with ammonium addition $(11.4 \%$ in above- and $8.3 \%$ in belowground tissues) compared to 24.4 and $31.9 \%$, respectively, for control tissues with no nutrient supply. In the other treatments, this $\mathrm{C}$ mobilisation was not as strong as with ammonium enrichment.
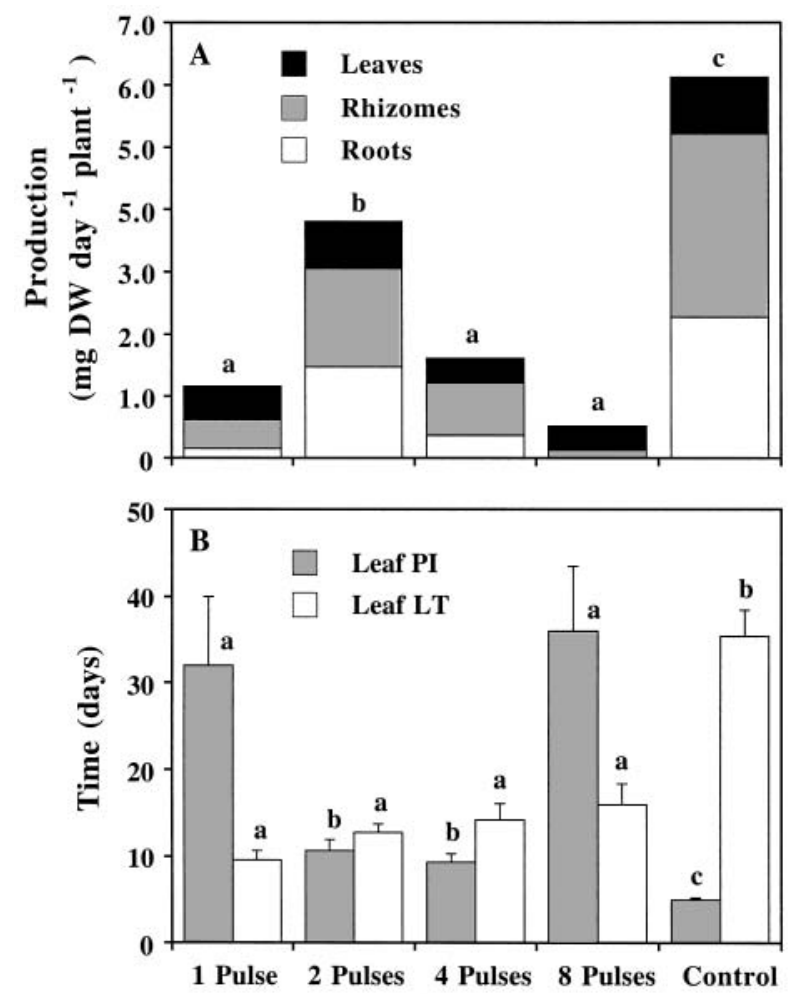

Fig. 6. Zostera noltii. Effect of the frequency of ammonium enrichment with different pulses of a similar final dose $(200 \mu \mathrm{M})$ in the laboratory on (A) primary production of above- and belowground tissues; (B) plastochron interval (PI) and leaf-loss time (LT). Ammonium pulses were added as described for Fig. 5. Letters above bars as in Fig. 3. Data are means of 6-8 separate plants; bars represent SE 
The data on internal composition for the pulse experiments carried out in the laboratory (using winter plants) and in the field (spring; April 1999) are shown in Table 2. Unfortunately, there are no data from the winter fiels trial, because of the low plant biomass recovered from the field. In the laboratory experiment, ammonium pulses induced a slight increase in internal $\mathrm{N}$ in both above- and belowground tissues. As a result, $\mathrm{C}: \mathrm{N}$ ratios remained low and the N:P ratio unchanged. Among the non-structural carbohydrates, sucrose content decreased as a result of ammonium addition, as in the previous experiment (Table 1), while starch was little affected, even increasing in concentration. As a result of sucrose mobilisation, sucrose- $\mathrm{C}$ was at a very low, critical level in relation to total C pool $(4.2 \%$ in above- and $9.3 \%$ in belowground tissues).

In the spring trial, the internal composition responded differently. The high growth rates measured in the field (in both the above- and belowground tissues) with ammonium enrichment resulted in a dilution effect, whereby the tissue $\mathrm{N}$ content of the plants decreased to values similar to those of the control. The
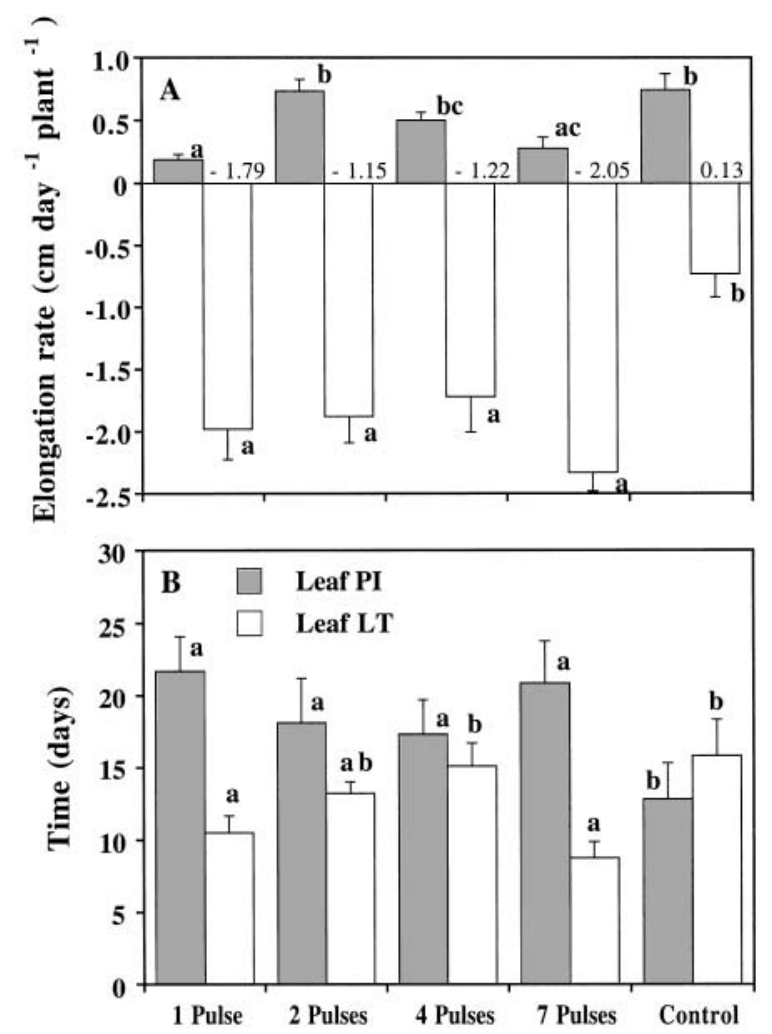

Fig. 7. Zostera noltii. Effect of the frequency of ammonium enrichment (winter trial) with different ammonium pulses added in the field on (A) gross growth rates (shaded bars) and leaf-loss rates (open bars) (numbers inside graph denote net growth rates); and (B) plastochron interval (PI) and leaf-loss time (LT). Letters above bars as in Fig. 3. Data are means of 8 to 10 separate plants; bars represent SE

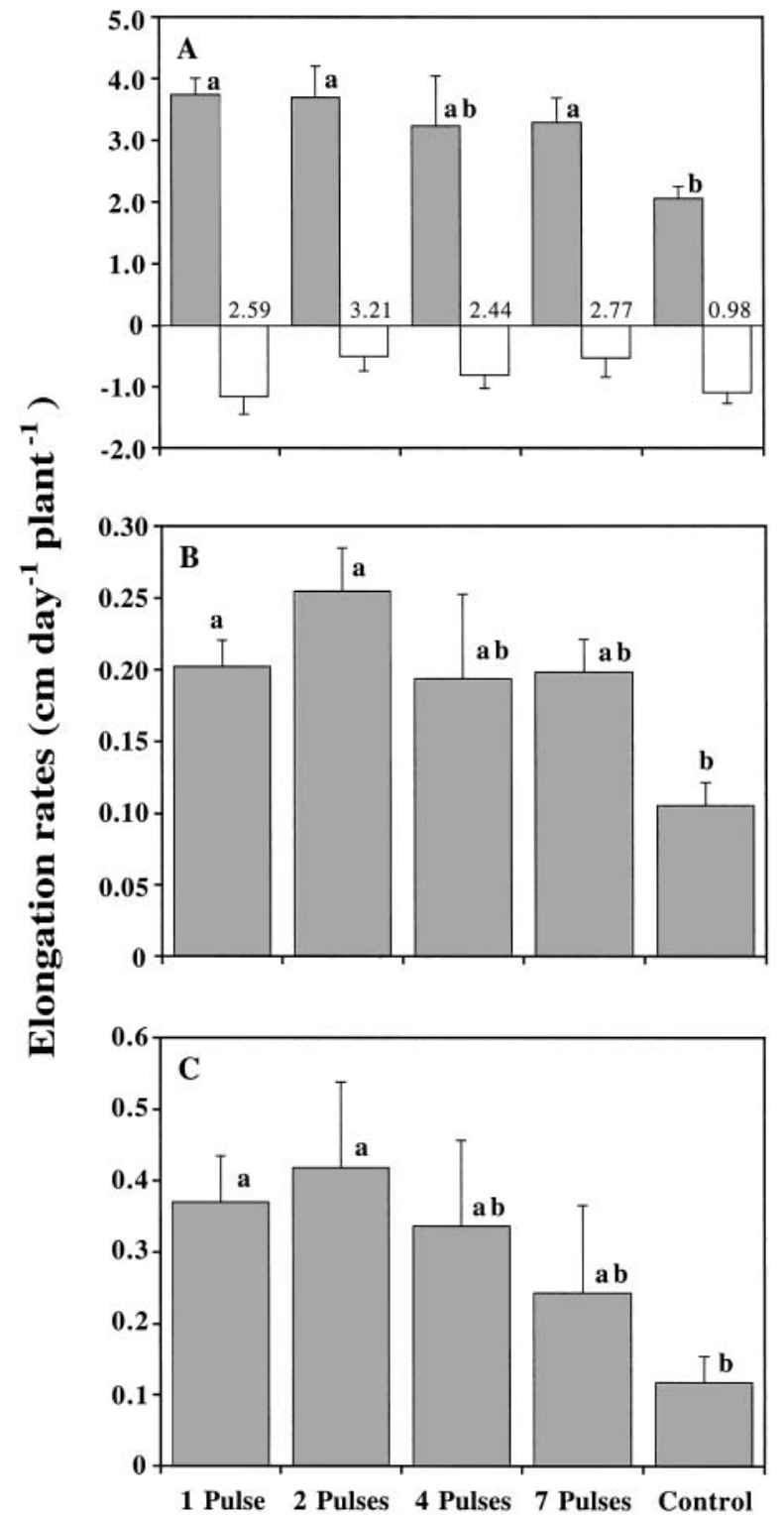

Fig. 8. Zostera noltii. Effect of the frequency of ammonium enrichment (spring trial) with different ammonium pulses added in the field on elongation rates of (A) shoots, (B) rhi-

zomes and $(\mathrm{C})$ roots. Further details as in Fig. 3 legend

lower tissue $\mathrm{N}$ content following ammonium enrichment resulted in slightly higher $\mathrm{C}: \mathrm{N}$ ratios, as the $\mathrm{C}$ content of the plants was not influenced by ammonium additions (data not shown). On the other hand, both above- and belowground tissues exhibited greater loss of tissue $\mathrm{P}$ than of tissue $\mathrm{N}$ (data not shown). As a result, tissue N:P increased with ammonium enrichment. Among the non-structural carbohydrates, starch was little affected by ammonium addition; sucrose was not mobilised, but accumulated in above- and belowground tissues, reaching concentrations higher than those in the control without ammonium supply. Thus, 

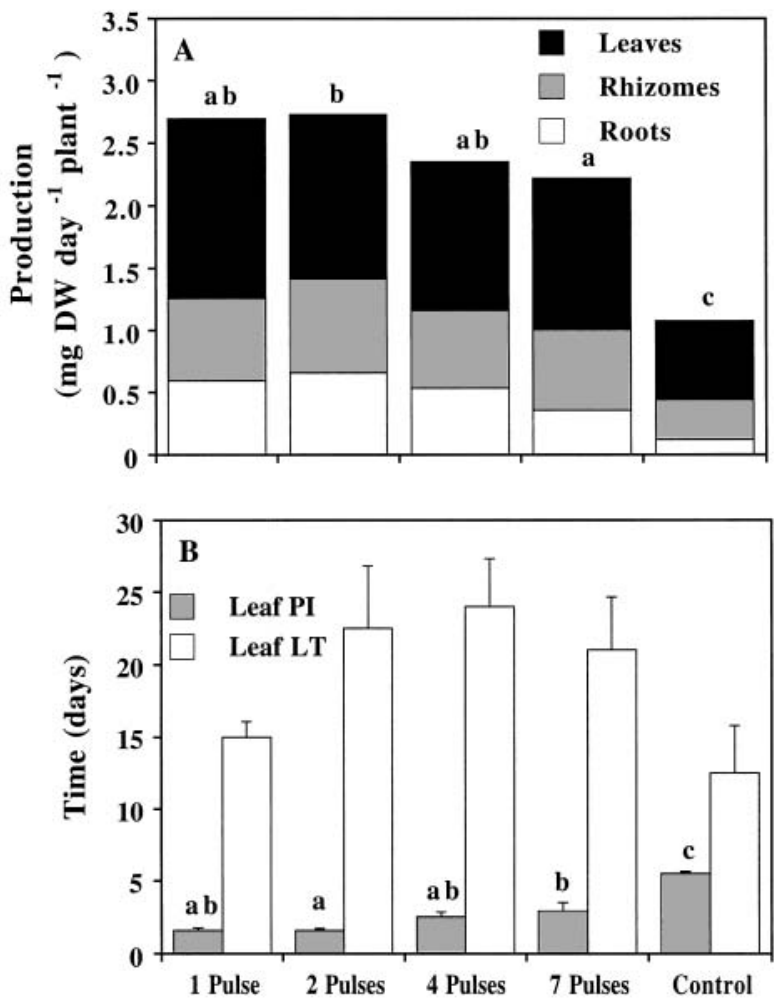

Fig. 9. Zostera noltii. Effect of the frequency of ammonium enrichment (spring trial) with different ammonium pulses added in the field on (A) primary production of above- and belowground tissues; and (B) plastochron interval and leafloss time. Letters above bars as in Fig. 3. Data are means of 8 to 10 separate plants; bars represent SE

sucrose-C represented a higher proportion of the total $\mathrm{C}$ pool than in the previous experiments $(16.7 \%$ in above- and $20 \%$ in belowground tissues).

Table 1. Zostera noltii. Internal $\mathrm{N}$ content, C:N and N:P atomic ratios, sucrose, starch content, and sucrose:C ratio in the laboratory experiment using different nutrient enrichments

\begin{tabular}{|lcccccc|}
\hline \multicolumn{2}{|c}{$\begin{array}{c}\mathrm{N} \\
(\% \mathrm{DW})\end{array}$} & $\mathrm{C}: \mathrm{N}$ & $\mathrm{N}: \mathrm{P}$ & $\begin{array}{c}\text { Sucrose } \\
\left(\mathrm{mg} \mathrm{g}^{-1} \mathrm{DW}\right)\end{array}$ & $\begin{array}{c}\text { Starch } \\
\left(\mathrm{mg} \mathrm{g}^{-1} \mathrm{DW}\right)\end{array}$ & $\begin{array}{c}\text { Sucrose:C } \\
(\% \mathrm{C})\end{array}$ \\
\hline \multicolumn{2}{l}{ Aboveground tissues } \\
Initial & 3.34 & 12.2 & 40.4 & 108.0 & 3.83 & 13.1 \\
Control & 1.51 & 22.5 & 33.9 & 168.7 & 4.34 & 24.4 \\
$+\mathrm{N}$ & 2.17 & 16.4 & 42.7 & 82.7 & 5.07 & 11.4 \\
$+\mathrm{P}$ & 1.44 & 23.4 & 33.0 & 220.1 & 4.83 & 32.0 \\
$+\mathrm{N}+\mathrm{P}$ & 1.78 & 19.5 & 37.6 & 122.7 & 6.30 & 17.3 \\
Belowground tissues & & & & & \\
Initial & 2.02 & 15.0 & 13.8 & 205.8 & 10.96 & 33.2 \\
Control & 0.71 & 48.8 & 14.8 & 224.8 & 11.84 & 31.9 \\
$+\mathrm{N}$ & 1.70 & 20.4 & 20.3 & 58.3 & 8.65 & 8.3 \\
$+\mathrm{P}$ & 0.74 & 42.2 & 30.2 & 84.6 & 8.49 & 13.3 \\
$+\mathrm{N}+\mathrm{P}$ & 0.95 & 36.2 & 19.6 & 180.6 & 9.81 & 25.8 \\
\hline
\end{tabular}

\section{DISCUSSION}

The results show that ammonium has an inhibitory effect on growth and survival of the seagrass Zostera noltii. In a recent review of nitrogen and phosphorus metabolism in seagrasses, Touchette \& Burkholder (2000a) reported a variety of seagrass responses to nutrient enrichment. One response was a negative physiological response and inhibition of growth as a result of nitrogen enrichment. Although it is well established that eutrophication stimulates algal overgrowth, causing light reduction and decline in seagrass biomass (Valiela et al. 1997), both nitrate (Burkholder et al. 1992, 1994) and ammonium (van Katwijk et al. 1997) can also have a direct inhibitory effect on Zostera marina. While the nitrate effect is thought to arise from internal $\mathrm{C}$ limitation, ammonium toxicity is thought to be a consequence of the uncoupling of ATP synthesis during photosynthesis (Touchette \& Burkholder 2000a).

Toxicity of ammonium depended on the time of year. Whereas a toxic effect was found in winter, in both the laboratory and the field, growth rates and primary production were both enhanced in spring during the field experiments. The main variable involved in this differential response seems to be sucrose, which is the main storage carbohydrate in most seagrasses (Pirc 1989, Touchette \& Burkholder 2000b). While there was a drop in sucrose content down to very low, critical levels in response to ammonium enrichment in winter, this metabolite was not mobilised, but was instead accumulated in the tissues in spring. Fig. 10 presents the primary production (as \% of control without nutrient addition) as a function of the degree of sucrose mobilisation (negative values, \%) or accumulation (positive values, \%) in above- and belowground tissues. Several trends are apparent: (1) repression of growth as a result of nutrient addition was always accompanied by sucrose mobilisation, whereas sucrose accumulation occurred in controls with no nutrient addition. (2) Spring patterns differed from winter patterns in that spring growth was stimulated by ammonium enrichment, and there was an accumulation of sucrose in aboveground tissues whereas, despite increased growth, sucrose levels remained fairly constant in belowground tissues. Similar results were recorded for Zostera noltii overgrown by Ulva spp. mats (triangles in Fig. 10, from Brun 1999): here too, repression of growth was accompanied by sucrose mobilisation. 
Table 2. Zostera noltii. Internal $\mathrm{N}$ content, $\mathrm{C}: \mathrm{N}$, and $\mathrm{N}: \mathrm{P}$ atomic ratios, sucrose, starch content, and sucrose:C ratio in the laboratory experiment and in the spring trial using different ammonium pulses

\begin{tabular}{|c|c|c|c|c|c|c|}
\hline & $\begin{array}{c}\mathrm{N} \\
(\% \mathrm{DW})\end{array}$ & $\mathrm{C}: \mathrm{N}$ & $\mathrm{N}: \mathrm{P}$ & $\begin{array}{c}\text { Sucrose } \\
\left(\mathrm{mg} \mathrm{g}^{-1} \mathrm{DW}\right)\end{array}$ & $\begin{array}{c}\text { Starch } \\
\left(\mathrm{mg} \mathrm{g}^{-1} \mathrm{DW}\right)\end{array}$ & $\begin{array}{c}\text { Sucrose:C } \\
(\% \text { C })\end{array}$ \\
\hline \multicolumn{7}{|c|}{ Laboratory experiment (winter) } \\
\hline Initial & 3.45 & 12.3 & 63.9 & 63.1 & 4.08 & 7.3 \\
\hline $\mathrm{NH}_{4}{ }^{+}$pulses (mean) & 3.60 & 12.0 & 55.2 & 30.8 & 5.06 & 4.2 \\
\hline \multicolumn{7}{|l|}{ Belowground tissues } \\
\hline Initial & 1.55 & 23.8 & 19.2 & 99.4 & 3.81 & 13.2 \\
\hline $\mathrm{NH}_{4}{ }^{+}$pulses (mean) & 2.20 & 15.3 & 24.7 & 62.4 & 5.87 & 9.3 \\
\hline \multicolumn{7}{|c|}{ Field experiment (spring trial) } \\
\hline \multicolumn{7}{|l|}{ Aboveground tissues } \\
\hline Initial & 3.46 & 12.2 & 16.2 & 53.9 & 1.83 & 6.3 \\
\hline Control & 2.56 & 14.2 & 26.8 & 73.9 & 3.90 & 10.0 \\
\hline $\mathrm{NH}_{4}{ }^{+}$pulses (mean) & 2.50 & 15.6 & 32.9 & 132.0 & 4.29 & 16.7 \\
\hline \multicolumn{7}{|l|}{ Belowground tissues } \\
\hline Initial & 1.75 & 20.5 & 10.2 & 132.3 & 8.18 & 18.1 \\
\hline Control & 1.43 & 22.8 & 12.6 & 95.3 & 5.18 & 14.4 \\
\hline $\mathrm{NH}_{4}{ }^{+}$pulses (mean) & 1.41 & 25.4 & 18.9 & 145.3 & 7.12 & 20.0 \\
\hline
\end{tabular}

On a seasonal basis, sucrose content was minimal in winter and spring (accompanied by Ulva spp. overgrowth) and maximal in summer and autumn, correlating fairly well with in situ growth and primary production (Brun et al. unpubl. data). The present results and those of Brun et al. suggest $\mathrm{N}$-induced internal C limitation in winter, as already described for microalgae (Turpin 1991), macroalgae (Vergara et al. 1995, 1997), and seagrasses (Touchette \& Burkholder 2000a). In spring, with higher light and temperature levels, the photosynthetic $\mathrm{C}$ flux is higher, and seems sufficient to meet increased internal $\mathrm{C}$ demands arising from $\mathrm{N}$ assimilation, thus alleviating the toxic effect. The ratio sucrose: $\mathrm{C}$ is indicative of carbon partitioning between different metabolic pathways (e.g. Vergara et al. 1995). The sucrose:C ratio reached lowest levels when the toxic effect was highest. In such cases, the major inhibitory effect was on root and rhizome production, indicating the lack of belowground $\mathrm{C}$ reserves to sustain growth of meristematic tissues in this species.

In regard to phosphate addition, this nutrient did not cause a significant reduction in growth. In addition to lacking a negative effect, phosphate alleviated ammonium toxicity. Phosphorus limitation can depress photosynthesis, as the $\mathrm{P}$ limitation can affect the rate of synthesis and regeneration of substrates in the CalvinBenson cycle (Dietz \& Foyer 1986, Woodrow \& Berry 1988). In addition, phosphorus is important in metabolic energy transfer (Stitt 1997).
Thus, when $\mathrm{C}$ turnover increases as a result of $\mathrm{N}$ assimilation, phosphorus demands would be expected to increase also (Touchette \& Burkholder 1999). One interesting result that deserves future investigation is the accumulation of sucrose in leaves accompanied by its mobilisation in belowground tissues after phosphate addition. This resulted in more sucrose in the leaves

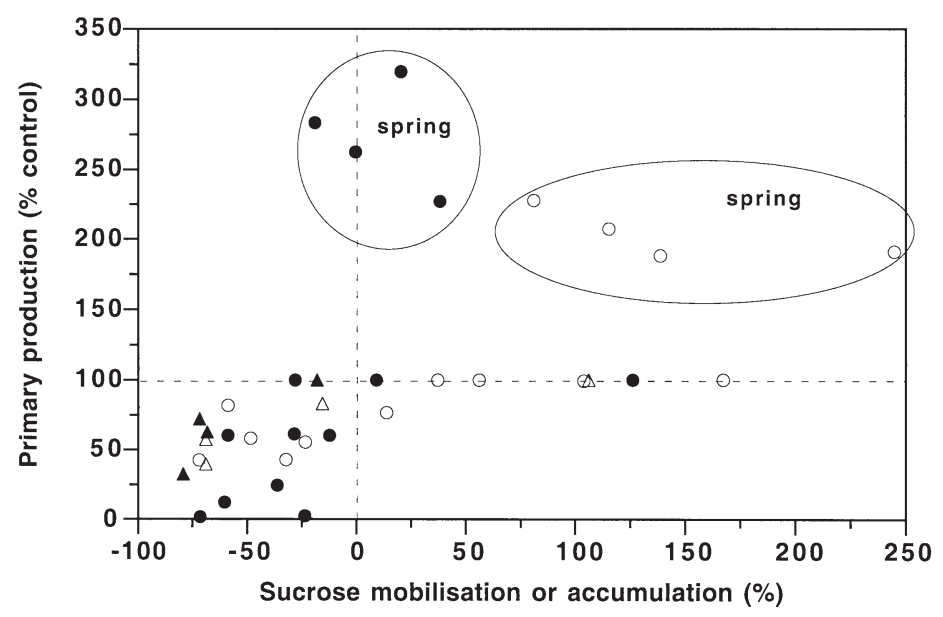

Fig. 10. Zostera noltii. Primary production (\% of control without nutrient addition) as a function of the degree of mobilisation (negative values) or accumulation (positive values) of sucrose in above- (open symbols) and belowground tissues (solid symbols). The degree of sucrose mobilisation/accumulation was calculated as the difference between final and initial concentrations divided by the initial content. $(\mathbf{0}, \mathbf{\bullet})$ All data from the experiments described in this study; encircled data points correspond to the spring experiment; $(\boldsymbol{\Delta}, \mathbf{\Lambda})$ shading experiment with Ulva spp. mats (from Brun 1999) 
than in the rhizomes, which is unusual (Touchette \& Burkholder 2000b). Most photosynthetic products are exported from the chloroplast as triose phosphates in exchange for inorganic phosphate (Lambers et al. 1999). Thus, increased availability of phosphate will enhance the export of carbohydrates. In our study, phosphate addition seemed to enhance the transport of sucrose from below- to aboveground tissues.

Ammonium toxicity was affected by the frequency of the ammonium pulses in both the laboratory and the field. The major inhibitory effect was observed at low (1 pulse of high magnitude) and high frequencies (8 pulses of low magnitude), with a lower toxic effect at intermediate frequencies ( 2 and 4 pulses). It seems that continuous exposure to ammonium negatively affected growth through a continuous supply of nitrogen that increased carbon demands and thus drained the carbon pool. Ammonium transport has an important passive component, which is not regulated (Touchette \& Burkholder 2000a), and this ammonium must be assimilated into amino acids to avoid negative effects on photosynthesis. Thus, a continuous ammoniuminduced stress (pulse every $2 \mathrm{~d}$ ) has a stronger effect than more widely spaced pulses. At the other extreme, an initial high dose of ammonium can exceed the capacity of the seagrass to assimilate nitrogen into carbon skeletons, causing a high transitory drop in carbon (Turpin 1991), which may enhance the negative effect of ammonium on photosynthesis. This dependence on pulse frequency merits closer examination in the future.

In our study, ammonium was supplied to the leaves, while a high proportion of sucrose reserves were allocated to belowground tissues. Rhizomes and roots were anchored to an agar-solidified substratum, which obviously lacked nutrients. Thus, when ammonium was added, $C$ transport from roots and rhizomes to the leaves was necessary, and/or nutrients had to be transported from the leaves to belowground tissues. Data on internal composition indicated a higher belowground $\mathrm{N}$ content and a lower belowground sucrose content than in the control in response to ammonium enrichment (Tables $1 \& 2$ ). Moreover, the decrease in belowground tissue $\mathrm{N}$ in plants with no ammonium enrichment (Table 1) suggests an important contribution of belowground tissues to support the total $\mathrm{N}$ demand, since these plants grew in an unenriched substratum.

In conclusion, ammonium has a toxic effect on survival and growth of Zostera noltii depending on the internal $\mathrm{C}$ balance (photosynthesis and sucrose reserves) to sustain $\mathrm{N}$ assimilation. Phosphate alleviates this toxicity which, depending on the frequency (low or high) of ammonium addition, can be chronic (frequent, low magnitude) or acute (infrequent, high magnitude).
Acknowledgements. This study was supported by the project MAR99-0561 of the Spanish National Programme in Marine Science and Technology from the Ministerio Español de Ciencia y Tecnología. F.G.B. holds a grant from the Ministerio Español de Educación, Cultura y Deportes. The authors wish to thank the reviewers for their valuable criticisms.

\section{LITERATURE CITED}

Alcoverro T, Zimmerman RC, Kohrs DG, Alberte RS (1999) Resource allocation and sucrose mobilization in lightlimited eelgrass Zostera marina. Mar Ecol Prog Ser 187: 121-131

APHA (American Public Health Association) (1992) Standard methods for the examination of water and wastewater, 18th edn. American Public Health Association, Washington, DC

Brun FG (1999) Patrones estructurales y dinámicos de las praderas de Zostera noltii Hornem. Del Parque Natural de la Bahía de Cádiz. MSc thesis, Universidad de Cádiz

Burkholder JM, Mason KM, Glasgow HB (1992) Watercolumn nitrate enrichment promotes decline of eelgrass Zostera marina: evidence from seasonal mesocosm experiments. Mar Ecol Prog Ser 81:163-178

Burkholder JM, Glasgow HB Jr, Cooke JE (1994) Comparative effects of water-column nitrate enrichment on eelgrass Zostera marina, shoalgrass Halodule wrightii, and widgeongrass Ruppia maritima. Mar Ecol Prog Ser 105: $121-138$

Carreira J, Clavero V, Gálvez JA, Guevara J and 7 others (1995) Eutrophication processes in estuaries situated at the end of small catchment areas. In: Kammermans $\mathrm{P}$, Nienhuis PH (eds) Eutrophication and macrophytes. Comn. No 2049, Netherland Institute of Ecology, Maarssen, p 113-116

Dietz KJ, Foyer C (1986) The relationship between phosphate status and photosynthesis in leaves; reversibility of the effects of phosphate deficiency on photosynthesis. Planta 167:376-381

Foreman K, Valiela I, Sardá R (1995) Controls of benthic marine food webs. Sci Mar 59(1):119-128

González-Gordillo JI (1999) Planktonic larval stages of decapod crustaceans from Cádiz and Algeciras bays (SW Spain): morphological and ecological aspects. $\mathrm{PhD}$ dissertation, University of Cádiz

Gómez-Parra A (1978) Estudio de la influencia de vertidos urbanos en las aguas del caño de Sancti Petri. MSc thesis, Universidad de Cádiz

Hernández I, Peralta G, Pérez-Lloréns JL, Vergara JJ, Niell FX (1997) Biomass and dynamics of growth of Ulva species in Palmones River Estuary. J Phycol 33:764-772

Lambers H, Chapin FS III, Pons TL (1999) Plant physiological ecology. Springer, New York

Mann KH (2000) Ecology of coastal waters with implications for management, 2nd edn. Blackwell Science, Oxford

Marschner H (1995) Mineral nutrition of higher plants, 2nd edn. Academic Press, New York

Neckles HA, Wetzel RL, Orth RJ (1993) Relative effects of nutrient enrichment and grazing on epiphyte-macrophyte (Zostera marina L.) dynamics. Oecologia 93:285-295

Pedersen MF, Borum J (1996) Nutrient control of algal growth in estuarine waters. Nutrient limitation and the importance of nitrogen requirements and nitrogen storage among phytoplankton and species of macroalgae. Mar Ecol Prog Ser 142:261-272

Peralta G, Pérez-Lloréns JL, Hernández I, Vergara JJ, Bartual 
A, Brun F, Gálvez JA, García CM (2000a) Morphological and physiological differences of two morphotypes of Zostera noltii Hornem from the southwestern Iberian Peninsula. Helgol Mar Res 54:80-86

Peralta G, Pérez-Lloréns JL, Brun F, Hernández I, Vergara JJ (2000b) Vegetative growth of Zostera noltii in a biphasic medium. Implications for ecophysiological experiments. Biol Mar Medit 7:111-114

Pirc H (1989) Seasonal changes in soluble carbohydrates, starch, and energy content in Mediterranean seagrasses. PSZN I: Mar Ecol 10:97-106

Risgaard-Petersen N, Dalsgaard T, Rysgaard S, Christensen PB, Borum J, McGlathery K, Nielsen LP (1998) Nitrogen balance of a temperate eelgrass Zostera marina bed. Mar Ecol Prog Ser 174:281-291

Short FT, McRoy CP (1984) Nitrogen uptake by leaves and roots of the seagrasss Zostera marina L. Bot Mar 27: 547-555

Short FT, Wyllie-Echevarria S (1996) Natural and humaninduced disturbance of seagrasses. Environ Conserv 23: 17-27

Short FT, Burdick DM, Kaldy JE (1995) Mesocosm experiments quantify the effects of eutrophication on eelgrass, Zostera marina. Limnol Oceanogr 40:740-749

Stitt M (1997) The flux of carbon between the chloroplast and the cytoplasm. In: Dennis DT, Turpin DH, Lefebvre DD, Layzell DB (eds) Plant metabolism. Longman Scientific and Technical, Singapore, p 382-400

Touchette BW, Burkholder JM (1999) Phosphorus availability and plant metabolism in a submersed marine angiosperm (Zostera marina L.): an ecological perspective. In: Lynch JP, Deikman J (eds) Phosphorus in plant biology: regulatory roles in molecular, cellular, organismic, and ecosystem processes. Current topics in plant physiology. American Society of Plant Physiologist, Rockville, MD, p 309-310

Touchette BW, Burkholder JM (2000a) Review of nitrogen and phosphorus metabolism in seagrasses. J Exp Mar Biol Ecol 250:133-167

Touchette BW, Burkholder JM (2000b) Overview of the

Editorial responsibility: Otto Kinne (Editor),

Oldendorf/Luhe, Germany physiological ecology of carbon metabolism in seagrasses. J Exp Mar Biol Ecol 250:169-205

Tovar A, Moreno C, Mánuel-Vez MP, García-Vargas M (2000) Environmental impacts of intensive aquaculture in marine waters. Water Res 34:334-342

Turpin DH (1991) Effects of inorganic N availability on algal photosynthesis and carbon metabolism. J Phycol 27:14-20

Valiela I, McClelland J, Hauxwell J, Behr PJ, Hersh D, Foreman K (1997) Macroalgal blooms in shallow estuaries: controls and ecophysiological and ecosystem consequences. Limnol Oceanogr 42:1105-1118

van Katwijk MM, Vergeer LHT, Schmitz GHW, Roelofs JGM (1997) Ammonium toxicity in eelgrass Zostera marina. Mar Ecol Prog Ser 157:159-173

Vergara JJ, Bird KT, Niell FX (1995) Nitrogen assimilation following $\mathrm{NH}_{4}{ }^{+}$pulses in the red alga Gracilariopsis lemaneiformis. Effect on C metabolism. Mar Ecol Prog Ser 122: $253-263$

Vergara JJ, Niell FX, Bird KT (1997) A dynamic model of transient $\mathrm{NH}_{4}{ }^{+}$assimilation in red algae. Mar Ecol Prog Ser 148:295-307

Williams SL, Ruckelshaus MH (1993) Effects of nitrogen availability and herbivory on eelgrass (Zostera marina) and its epiphytes. Ecology 74:904-918

Woelkerling WJ, Spencer KG, West JA (1983) Studies on selected corallinaceae (Rhodophyta) and other macroalgae in a defined marine culture medium. J Exp Mar Biol Ecol 67:61-77

Woodrow IE, Berry JA (1988) Enzymatic regulation of photosynthetic $\mathrm{CO}_{2}$ fixation in $\mathrm{C}_{3}$ plants. Annu Rev Plant Physiol Plant Mol Biol 39:533-594

Zar JH (1984) Biostatistical analysis, 2nd edn. Prentice-Hall, Englewood Cliffs, NJ

Zieman JC (1974) Methods for the study of the growth and production of the turtle grass, Thalassia testudinum König. Aquaculture 4:1239-143

Zimmerman RC, Smith RD, Alberte RS (1987) Is growth of eelgrass nitrogen limited? A numerical simulation of the effects of light and nitrogen on the growth dynamics of Zostera marina. Mar Ecol Prog Ser 41:167-176

Submitted: November 20, 2000; Accepted: June 7, 2001 Proofs received from author(s): December 14, 2001 